\title{
Deteksi Buah Menggunakan Supervised Learning dan Ekstraksi Fitur untuk Pemeriksa Harga
}

\author{
http://dx.doi.org/10.28932/jutisi.v6i3.3029
}

\author{
Kristiawan $^{\# 1}$, Deon Diamanta ${ }^{\# 2}$, Try Atmaja ${ }^{\# 3}$, Andreas Widjaja ${ }^{\bowtie \# 4}$ \\ \#Jurusan Magister Ilmu Komputer,Universitas Kristen Maranatha \\ Jl. Surya Sumantri no. 65, Sukawarna \\ ${ }^{1}$ mi1979005@student.it.maranatha.edu \\ ${ }^{2}$ mi1979004estudent.it.maranatha.edu \\ ${ }^{3}$ mi1979003estudent.it.maranatha.edu \\ ${ }^{4}$ andreas.widjajalit.maranatha.edu
}

\begin{abstract}
The role of technology like Computer Vision in the business world is growing over time. This is no exception to the supermarket business. This study aims to build a prototype to help supermarket customers perform independent service and provide efficiency for companies engaged in the supermarket sector. This system can detect and recognize fruits using a standard camera and provide price information to users. This system utilizes the k-Nearest Neighbors and Histogram of Oriented Gradient algorithms to recognize fruit objects. By using these two algorithms, feature extraction can be done in the form of color and shape of the object which is then classified. This study takes the fruit images as input and then the recognition system shows the fruit name and price information.
\end{abstract}

Keywords- fruit detection; HoG; k-NN; OpenCV

\section{Pendahuluan}

Peran serta teknologi dalam dunia bisnis kian besar, seiring dengan perkembangannya. Hal ini dimaksudkan untuk mempermudah proses-proses yang sering dilakukan dalam bisnis itu sendiri. Kini peran teknologi dapat kita jumpai dalam berbagai macam model bisnis, tidak berpaku pada dunia TI saja. Bisnis transportasi, bisnis makanan, hingga bisnis pengiriman barang dibuat jadi lebih mudah dan sederhana dengan adanya peran teknologi dalam model bisnisnya.

Bisnis lainnya seperti supermarket juga tidak luput dari adanya integrasi teknologi di dalamnya. Hal yang paling sering kita lihat seperti penggunaan mesin kasir yang pada waktu dulu hanya sekedar untuk menghitung transaksi konsumen dan menyimpan uang pembayaran dalam bentuk uang tunai, sekarang dengan adanya penerapan teknologi, mesin kasir terhubung dengan mesin Electronic Data Capture (EDC), barcode scanner, hingga Near Field
Communication untuk pembayaran [1].

Peran teknologi di dalam bisnis, selain mempermudah para pelaku bisnis dalam menjalankan kegiatan operasional bisnisnya, juga memiliki tujuan untuk meningkatkan efisiensi. Teknologi mendorong dan memungkinkan pemrosesan data yang lebih cepat, pengambilan informasi yang lebih mudah, dan dalam beberapa kasus - otomatisasi yang diberikan oleh teknologi dapat mengurangi atau bahkan menggantikan peran karyawan / tenaga manusia secara fisik.

Ketika manusia melakukan tugas, itu bisa memakan waktu dan memiliki potensi untuk terjadinya kesalahan manusia (human error). Ketika teknologi digunakan untuk proses kerja / operasional yang berulang, peluang untuk terjadinya kesalahan dapat dikurangi atau bahkan dihilangkan. Demikian juga dengan waktu yang dibutuhkan untuk menyelesaikan tugas dapat dipersingkat. Selain membuat proses jadi berjalan lebih cepat, teknologi juga mempermudah untuk memperoleh informasi terkini.

Melihat keberagaman teknologi yang semakin bertambah dan terintegrasi kepada hal yang tadinya sederhana namun terbilang rumit dan memakan waktu untuk dilakukan, tidak menutup kemungkinan hal seperti itu dapat diterapkan kepada hal-hal lainnya seperti alat price checker yang juga sering ditemui pada supermarket. Dengan teknologi berupa computer vision untuk mengenali objek, peran manusia dapat dikurangi atau dihilangkan [2].

Seiring waktu, tenaga manusia juga akan bertambah mahal. Sebagai opsi dalam pengembangan bisnis, tentunya lebih baik mencari opsi pengganti yang menawarkan biaya lebih rendah untuk jangka panjang, dengan kata lain menawarkan efisiensi. Dalam konteks ini, peran teknologi dalam bisnis juga menjadi pilihan yang menguntungkan.

Teknologi computer vision pada alat price checker di 
supermarket seperti yang disebutkan di atas memungkinkan konsumen yang berbelanja dapat melakukan kegiatan self service dengan melakukan scan barang kepada alat computer vision yang disediakan yang langsung dapat mengenali produk dan menunjukkan harga barang tersebut. Hal ini dapat dilakukan tanpa adanya peran serta dari karyawan seperti pada umumnya [3].

Konsumen tidak perlu mengetahui kode dari objek yang ingin dihitung. Konsumen hanya menunjukkan buah ke hadapan kamera, kamera akan mengenali objek tersebut dan memunculkan keterangan beserta harga dari buah tersebut. Dalam penelitian ini, objek akan difokuskan kepada buahbuahan. Penelitian ini mengarah kepada hal tersebut, walaupun masih beberapa langkah ke depan, yang akan dibuat baru pengenal buah saja [4].

Hasil dari penelitian ini adalah sebuah prototype sistem kamera yang menerima input berupa foto buah-buahan. Kamera ini terhubung dengan komputer / laptop, jadi setiap ada input berupa foto buah, input tersebut akan dimasukkan ke dalam algoritma machine learning. Kemudian pada hasil proses yang dikeluarkan oleh machine learning tersebut akan dilakukan mapping dengan database pada sistem. Kemudian harga dari buah tersebut akan muncul.

\section{A. Rumusan Masalah}

Bagaimana membuat sebuah sistem yang mampu mengenali buah-buahan dan membantu penghitungan harga dengan mudah bagi konsumen?

\section{B. Batasan Masalah}

Pembatasan masalah digunakan untuk menghindari adanya penyimpangan maupun pelebaran pokok masalah agar penelitian lebih terarah dan memudahkan dalam pembahasan sehingga tujuan penelitian akan tercapai. Batasan masalah dalam penelitian ini adalah sebagai berikut:

- Penelitian dilakukan untuk cakupan computer vision dalam mengenali objek buah-buahan pada supermarket;

- Sistem yang dibangun ini, berbentuk prototype yang diperuntukkan bagi konsumen supermarket sebagai user;

- Sistem ini dihubungkan dengan database list harga buah-buahan untuk penghitungan harga buah.

\section{Tujuan Penelitian}

Tujuan dari penelitian ini adalah membangun sebuah sistem yang memberikan efisiensi bagi perusahaan yang bergerak di bidang bisnis supermarket untuk memberikan kemudahan bagi konsumen dalam melakukan self service, memperoleh informasi harga buah-buahan dengan memanfaatkan teknologi computer vision.

\section{KAJIAN LITERATUR}

Dalam penelitian ini, menggunakan literatur-literatur yang terkait seputar computer vision, opencv, histogram of oriented gradient $(H o G)$, dan $k$-nearest neighbors $(k-N N)$.

\section{A. Computer Vision}

Computer vision, sering disingkat dengan CV, didefinisikan sebagai bidang studi yang berupaya mengembangkan teknik untuk membantu komputer "melihat" dan memahami konten gambar digital seperti foto dan video. Permasalahan computer vision tampak sederhana, namun tetap menjadi masalah yang masih belum dapat terpecahkan berdasarkan pada pemahaman yang terbatas tentang penglihatan biologis dan karena kompleksitas persepsi penglihatan dalam dunia fisik yang dinamis dan hampir tak terbatas.

Computer Vision adalah bidang studi yang berfokus pada masalah membantu komputer untuk melihat [5]. Pada tingkat abstrak, tujuan masalah computer vision adalah menggunakan data gambar yang diamati untuk menyimpulkan sesuatu tentang dunia. Computer vision sebagai bidang adalah batas intelektual. Seperti batas-batas lainnya, batas tersebut menarik dan tidak terorganisasi, dan sering kali tidak ada otoritas yang dapat diandalkan [6].

Banyak ide berguna yang tidak memiliki landasan teoritis, dan beberapa teori tidak berguna dalam praktiknya. Tujuan dari Computer vision adalah untuk memahami konten gambar digital. Biasanya, ini melibatkan pengembangan metode yang berupaya mereplikasi kemampuan penglihatan manusia. Memahami konten gambar digital mungkin melibatkan penggalian deskripsi dari gambar, yang dapat berupa objek, deskripsi teks, model tiga dimensi.

Sedangkan menurut pandangan lain, Computer vision adalah ekstraksi informasi secara otomatis dari gambar. Informasi dapat berarti apa saja mulai dari model 3D, posisi kamera, deteksi dan pengenalan objek hingga pengelompokan dan pencarian konten gambar [7].

Computer vision akan mengolah data berupa gambar dan video yang disebut Image Processing. Image Processing adalah proses membuat gambar baru dari gambar yang ada, biasanya menyederhanakan atau meningkatkan konten dengan cara tertentu. Ini adalah jenis pemrosesan sinyal digital dan tidak peduli dengan memahami konten suatu gambar. Contoh image processing meliputi :

- Menormalkan sifat fotometrik gambar, seperti kecerahan dan warna;

- Memotong batas gambar, seperti memusatkan objek pada foto;

- Menghapus noise digital dari suatu gambar, seperti artefak digital dari tingkat cahaya rendah.

Bidang computer vision masih memiliki tantangan besar dalam penerapannya. Tujuan dari computer vision adalah untuk mengekstraksi informasi yang berguna dari gambar. Ini telah membuktikan tugas yang sangat menantang; hal ini 
telah melibatkan ribuan pemikiran cerdas dan kreatif selama empat dekade terakhir.

Meskipun demikian, masih dianggap jauh untuk dapat membangun "mesin penglihatan" yang dapat digunakan untuk tujuan umum. Terdapat permasalahan-permasalahan tingkat tinggi yang memperoleh keuntungan dari penggunaan computer vision pada bidangnya masingmasing [8]:

- Optical Character Recognition (OCR);

- Machine inspection;

- Retail (automated checkouts);

- 3D model building;

- Medical imaging;

- Automotive safety;

- Motion capture;

- Surveillence;

- Fingerprint recognition and biometrics.

Banyak aplikasi computer vision yang populer melibatkan upaya untuk mengenali hal-hal dalam foto, sebagai contoh :

- Object classification;

- Object identification;

- Object verification;

- Object detection;

- Object segmentation;

- Object recognition.

\section{B. OpenCV}

Open Source Computer Vision Library (OpenCV) adalah perpustakaan perangkat lunak yang bersifat open source untuk machine learning dan computer vision. OpenCV dibangun untuk menyediakan infrastruktur umum untuk aplikasi computer vision dan untuk mempercepat persepsi mesin pada produk komersial. Menjadi produk berlisensi $B S D$, Open $C V$ memudahkan bisnis untuk memanfaatkan dan memodifikasi kode. Perpustakaan memiliki lebih dari 2500 algoritma yang dioptimalkan, yang mencakup serangkaian komprehensif computer vision dan algoritma machine learning yang mutakhir [9].

OpenCV dapat digunakan untuk mendeteksi dan mengenali bentuk / rupa dari wajah, mengidentifikasi objek, mengklasifikasikan tindakan manusia dalam video, melacak gerakan benda, mengekstraksi model objek 3D, menghasilkan awan titik 3D dari kamera stereo, menggabungkan beberapa gambar menjadi satu kesatuan untuk menghasilkan resolusi tinggi gambar seluruh adegan, temukan gambar serupa dari basis data gambar, hapus mata merah dari gambar yang diambil menggunakan lampu flash, mengikuti gerakan mata, mengenali pemandangan, membuat lapisan augmented reality, dan lainnya.

OpenCV memiliki antarmuka $\mathrm{C}++$, Python, Java dan MATLAB dan mendukung Windows, Linux, Android dan Mac OS. OpenCV sebagian besar condong ke aplikasi penglihatan realtime dan memanfaatkan instruksi $M M X$ dan
SSE saat tersedia. Dengan OpenCV, dapat dilakukan pengolahan gambar objek buah-buahan untuk supermarket.

\section{Histogram of Oriented Gradients ( $\mathrm{HoG})$}

HoG atau Histogram of Oriented Gradients adalah feature descriptor yang sering digunakan untuk mengekstrak fitur dari data gambar. Ini banyak digunakan dalam tugas computer vision untuk deteksi objek [10]. Feature descriptor adalah representasi gambar atau patch gambar yang menyederhanakan gambar dengan mengekstraksi informasi yang berguna dan membuang informasi asing.

Dalam HoG feature descriptor, distribusi (histogram) arah gradien (gradien berorientasi) digunakan sebagai fitur. Gradien (turunan x dan y) dari suatu gambar berguna karena nilai gradien di sekitar tepi dan sudut adalah besar (daerah dengan perubahan intensitas mendadak). Selain itu, daerah tepi dan sudut mengemas lebih banyak informasi tentang bentuk objek daripada daerah datar dari suatu gambar [11] Beberapa aspek penting $H O G$ yang membuatnya berbeda dari deskriptor fitur lainnya:

- Descriptor HOG berfokus pada struktur atau bentuk objek. Ini dilakukan dengan mengekstraksi gradien dan orientasi;

- Selain itu, orientasi ini dihitung dalam porsi 'terlokalisasi'. Ini berarti bahwa gambar lengkap dipecah menjadi daerah yang lebih kecil dan untuk setiap daerah, gradien dan orientasi dihitung;

- Akhirnya $H o G$ akan menghasilkan histogram untuk masing-masing wilayah ini secara terpisah. Histogram dibuat menggunakan gradien dan orientasi nilai piksel.

Secara keseluruhan, dapat didefinisikan sebagai berikut: feature descriptor $\mathrm{HoG}$ menghitung kemunculan orientasi gradien di bagian gambar yang dilokalkan. Feature descriptor $H o G$ dapat digunakan untuk mengekstraksi fitur berupa bentuk objek dan juga warna objek pada gambar. Keduanya dapat dilakukan dengan cara kerja yang serupa:

- Langkah pertama adalah melakukan preprocessing pada data gambar. Preprocessing data dapat dilakukan dengan cara resize gambar menjadi ukuran piksel yang lebih kecil dari gambar awal. Misalkan kita memiliki gambar awal dengan ukuran 180x280 piksel, maka kemudian dilakukan resize menjadi gambar dengan ukuran 64x128 piksel;

- Langkah kedua adalah melakukan kelkulasi gradien pada setiap piksel dalam gambar. Langkah ini akan menghasilkan dua buah matriks, satu matriks menyimpan gradien arah sumbu $\mathrm{x}$ dan satu matriks menyimpan gradien arah sumbu $y$;

- Langkah ketiga adalah menghitung magnitude dan orientasi gradien dari matriks yang diperoleh sebelumnya. Cara kerja $H o G$ terdapat pada Gambar 1. 


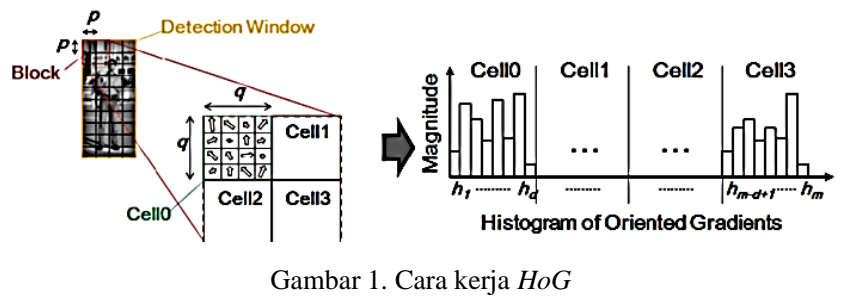

\section{K-Nearest Neighbors (knn)}

Algoritma K-Nearest Neighbors adalah algoritma pembelajaran mesin sederhana, mudah diterapkan yang dapat digunakan untuk memecahkan masalah klasifikasi dan regresi. Algoritma ini bekerja untuk pembelajaran dengan label atau supervised. Algoritma supervised learning adalah algoritma yang bergantung pada data input berlabel untuk mempelajari fungsi yang menghasilkan output yang sesuai ketika diberi data baru tanpa label. Algoritma knn mengasumsikan bahwa hal serupa ada dalam jarak dekat. Dengan kata lain, hal-hal serupa dekat satu sama lain [12].

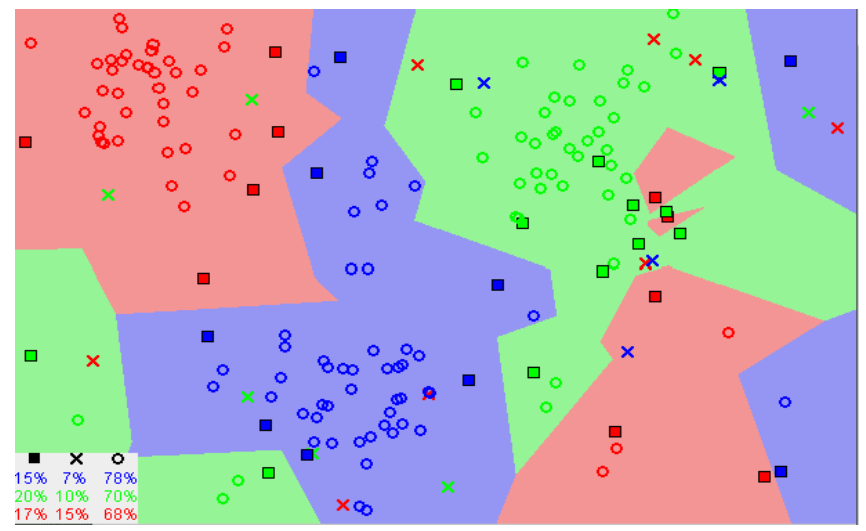

Gambar 2. Contoh K-Nearest Neighbors

Seperti pada contoh Gambar 2, bahwa sebagian besar waktu, titik data yang serupa dekat satu sama lain. Algoritma $k-N N$ bergantung pada asumsi tersebut, knn menangkap gagasan kesamaan (kadang-kadang disebut jarak, kedekatan, atau kedekatan). Cara yang digunakan adalah menghitung jarak kedekatan antara suatu titik dengan titik lainnya.

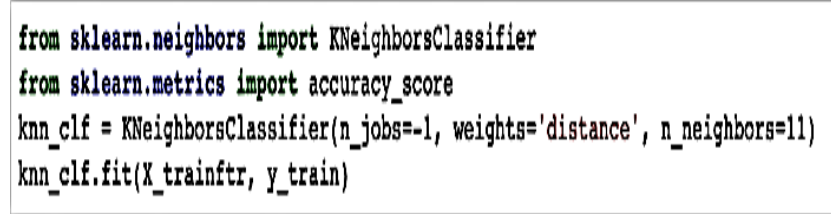

Gambar 3. Algoritma $k-N N$

Algoritma $k$-NN seperti pada Gambar 3 digunakan untuk mengklasifikasikan objek baru berdasarkan atribut dan training sample. Dalam implementasinya, algoritma ini memiliki keunggulan:

- Algoritma ini termasuk mudah digunakan;

- Tidak perlu membangun model, tuning parameter;
- Memiliki banyak kegunaan, bisa untuk klasifikasi atau regresi.

\section{PERANCANGAN}

Berikut pada Gambar 4 adalah rancangan flowchart yang akan digunakan. Pelanggan akan meletakan buah pada timbangan, lalu kamera akan mengambil gambar buah yang diletakkan oleh pelanggan tersebut. Gambar buah yang diambil oleh kamera akan menjadi input bagi sistem. Kemudian sistem akan mengenali jenis buah tersebut dan mengeluarkan informasi yang berisikan data nama buah dan harga buah berdasarkan satuan berat kilogram.

\section{A. Flowchart}

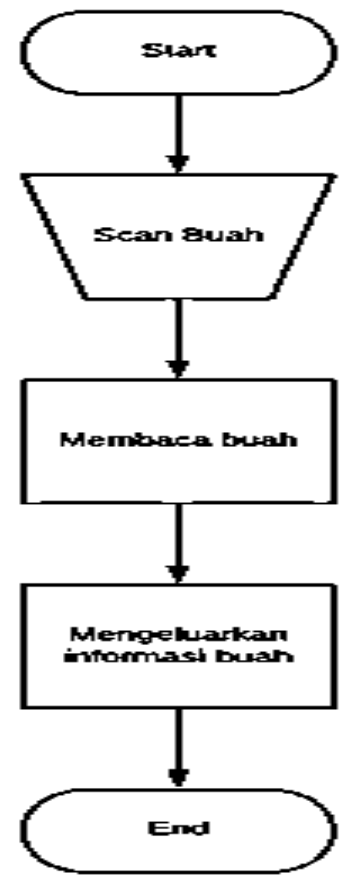

Gambar 4. Flowchart penelitian yang dilakukan

\section{METODOLOGI}

Dalam penelitian ini, tools yang digunakan adalah OpenCV, $H o G$, dan $k-N N$. Tugas dilakukan dengan mengikuti pedoman alur kerja / proses pembuatan model pembelajaran fruit detection seperti pada Gambar 5 berikut. 


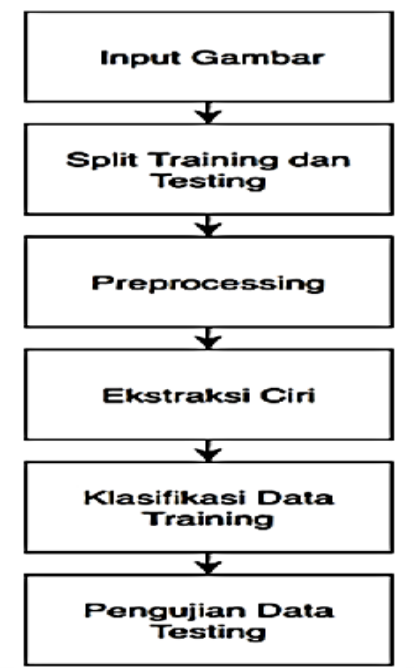

Gambar 5. Alur kerja Fruit Detection

Langkah pertama yang dilakukan adalah memasukan dataset sebanyak 9.695 gambar sebagai input yang terdiri atas:

- Buah apel (3.110 gambar);

- Buah pisang (2.838 gambar);

- Buah lemon (3.747 gambar).

Langkah kedua, dilakukan pemisahan (splitting) data menjadi data untuk training sebanyak $70 \%$ dan data untuk testing sebanyak $30 \%$.

\section{\# Split data training dan Testing 708 training, 308 testing \\ $X_{-}$train, $X_{-}$test, $y_{-}$train, $y_{-}$test = train test split $X_{-}$Colordes, y_Colordes, tes $t$ size $=0.30$, random state $=42$ )}

Gambar 6. Data dipisah untuk training dan testing

Setelah memisahkan data training dan testing pada Gambar 6, dilakukan preprocessing pada data gambar. Hal ini dilakukan dengan OpenCV di mana kegiatan yang dilakukan adalah sebagai berikut:

- Read image file;

- Deteksi objek pada gambar;

- Konversi warna;

- Crop;

- Resize.

Namun ada perbedaan dalam preprocessing antara gambar yang nantinya akan dilakukan ekstraksi fitur berdasarkan bentuk seperti terlihat pada Gambar 8 serta gambar yang dilakukan ekstraksi fitur berdasarkan warna [13]. Bagi gambar yang akan diekstraksi fitur berupa bentuk, dilakukan preprocessing berupa merubah warna objek menjadi grayscale. Sedangkan bagi gambar yang akan diekstraksi fitur berupa warna, dilakukan preprocessing berupa merubah warna $R G B$ menjadi $H S V$ seperti pada Gambar 7. Hasil dari preprocessing merubah warna $R G B$ menjadi $H S V$ dapat dilihat pada Gambar 9.

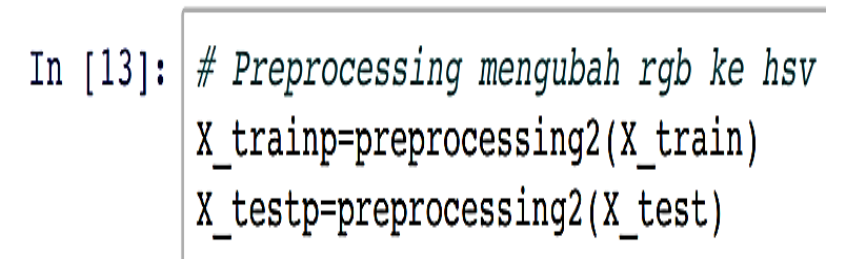

Gambar 7. Preprocessing untuk fitur warna
In [13]: \#Preprocessing conversi gambar ke gray x_trainp=preprocessing 1 ( $x_{\text {_train }}$ ) $x_{\text {_test }}=$ preprocessing 1 ( $\mathrm{x}$ _test)
In [14]: \# Cek data Preprocessing $72 \times 72$, lihat img $=x$ _trainp [1]
$y=y+t r a i n[1]$
plt.imshow (img, cmap="gray")
plt.xlabel (y)
plt.show()

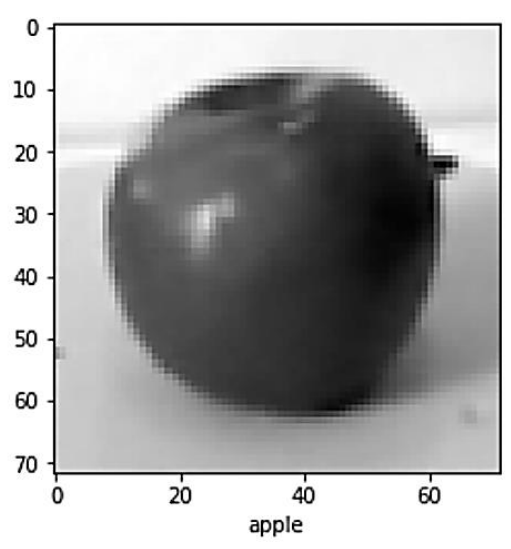

Gambar 8. Preprocesing untuk fitur bentuk
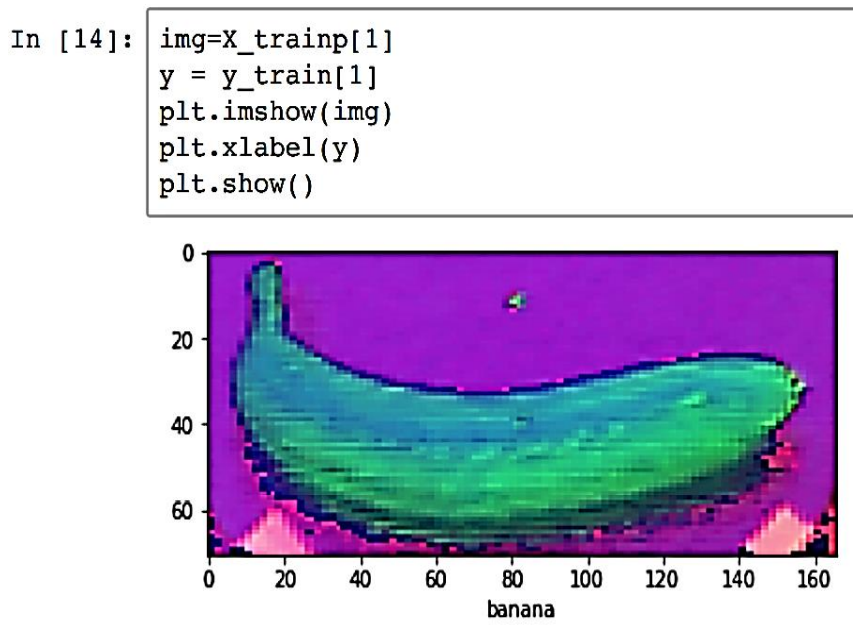

Gambar 9. Hasil preprocessing $r g b$ menjadi $h s v$ 
Data gambar yang sudah dilakukan preprocessing kemudian akan dilakukan ekstraksi fitur dengan $\mathrm{HoG}$ seperti pada Gambar 10 dan akan memberikan hasil akhir seperti pada Gambar 11. Fitur-fitur yang diekstraksi adalah bentuk objek pada gambar dan warna dari objek pada gambar.

\#Peature Extraction mengambil data2 yang penting saja dari 5184 feature menjadi 128 pixel saja

$X_{-}$trainftr-featureexxtraction ( $\chi_{-}$trainp)

$X_{-}$testftrafeatureExtractionl( $X_{-}$testp)

Gambar 10. Ekstraksi fitur dengan $H o G$

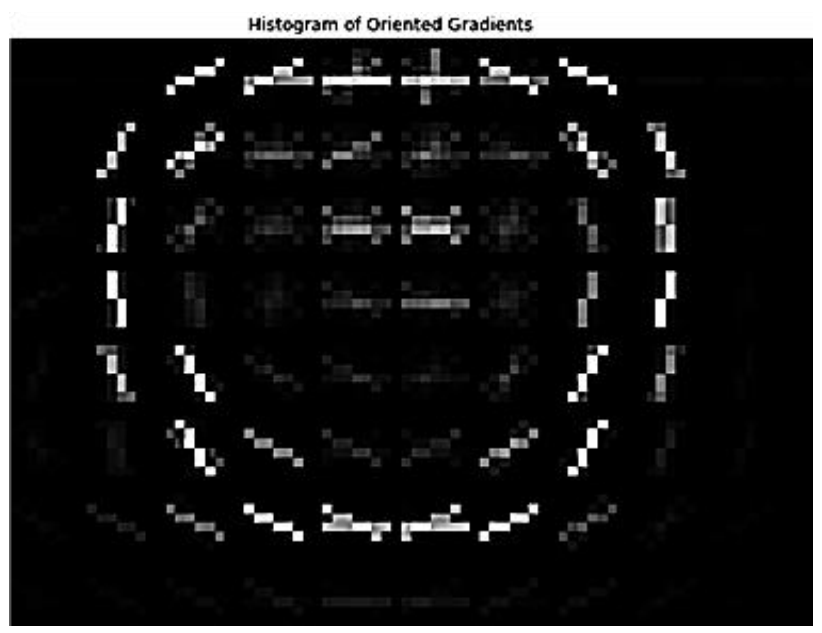

Gambar 11. Hasil ekstraksi fitur

Langkah selanjutnya yang dilakukan setelah mengekstraksi fitur dari gambar adalah melakukan klasifikasi berdasarkan jenis buah (apel, pisang, lemon). Klasifikasi seperti pada Gambar 12 dilakukan dengan menggunakan algoritma $k-N N$ (K-nearest neighbors).

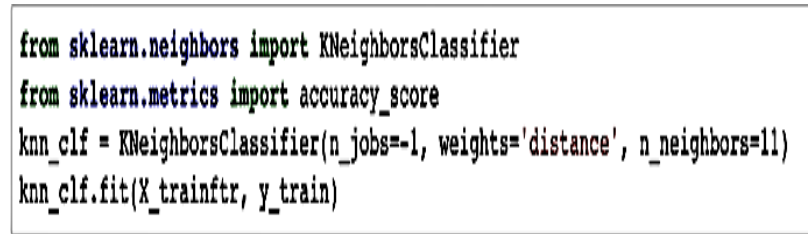

RNeighborsclassifier (algoritthn=' auto', leaf size=30, metric='minkowski',

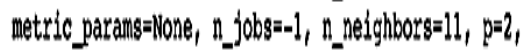
weightse' 'distance')

Gambar 12. Klasifikasi dengan $k-N N$

Selanjutnya dilakukan testing dengan data yang sudah dilakukan ekstraksi fitur bentuk dan fitur warna. Hasil testing Gambar 13 menunjukkan bahwa tingkat akurasi bagi fitur bentuk adalah sebesar 99,8\% dan bagi fitur warna adalah sebesar $99,7 \%$. Langkah berikutnya yang dilakukan adalah melakukan uji coba dengan data baru di luar dataset sebelumnya. Tujuannya adalah untuk mengetahui apakah prediksi buah dapat dilakukan dengan tepat seperti menggunakan dataset pada tahap sebelumnya. Jika hasil pengujian sukses membaca buah pada gambar baru, maka sistem yang dibentuk berhasil.

Gambar buah yang diperoleh dengan hasil capture dari kamera akan dilakukan preprocessing dan ekstraksi fitur seperti pada Gambar 14. Kemudian gambar yang diperoleh dijadikan sebagai input bagi sistem pengenalan buah-buahan. Sistem akan mengenali buah tersebut dan mencari informasi nilai harga dari buah tersebut. Untuk harga yang dimunculkan oleh sistem, tersedia dalam format daftar harga per satuan kilogram menggunakan sampel buatan terlebih dahulu untuk pengujian, bukan menggunakan data harga sebenarnya. Hasil keluaran dari sistem dapat dilihat pada Gambar 15.

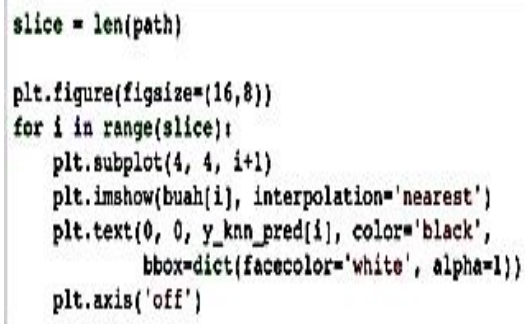

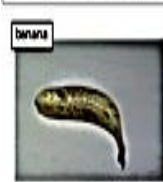

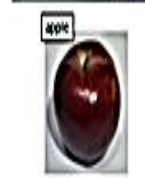

- man -
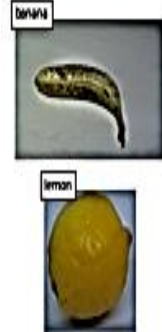
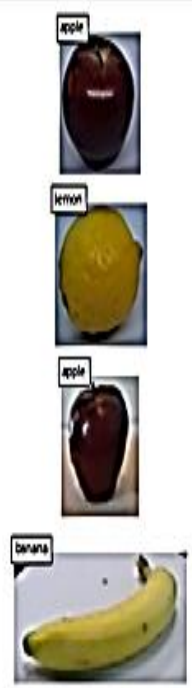

Gambar 13. Testing data gambar

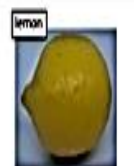

$+\infty$
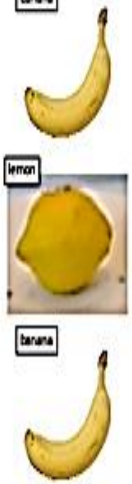

wot

$\cup$
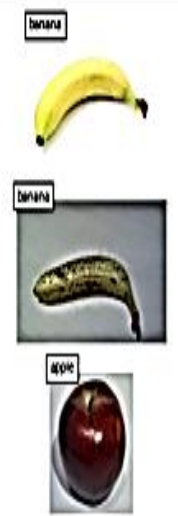


import numpy as ap
import cv2
import matplotlib.pyplot as plt
from skimage.transform import rescale, resize
cap = cv2.VideoCapture( 0 )
while('True):
\# Capture frame-by-frame
ret, frame = cap.read()
\# Our operations on the frame come here
buah - cv2.cvtColor(frame, cv2.coLOR_BGR2RGB)
\# Display the resulting frame
cv2.imshow('frame', buah)
if cv2.waitKey(1) \& OxFF = ord(' $q$ '):
$\quad$ break
\# When everything done, release the capture
cap.release()
cv2.destroyAllwindows()
\#img=resize(gray, (64, 128), anti_aliasing=True) \# test preprocessing
\#plt.imshow(img, cmap=' 'gray')
\#plt. show()
\# simpan gambar
cv2.imwrite('./uji_buah.jpg', frame)

Gambar 14. Input gambar buah melalui kamera

$$
\text { pred }=\text { knn_clf.predict([imgftr] ) }
$$

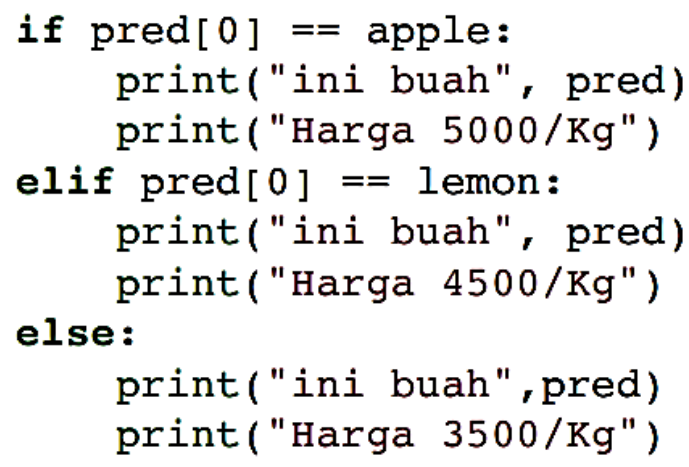

\section{ini buah ['banana'] Harga $3500 / \mathrm{Kg}$}

Gambar 15. Hasil prediksi informasi buah dan harganya

\section{RISIKO}

Dalam perancangan prototipe sistem pengenalan buahbuahan ini, selain memastikan sistem yang dibangun dapat digunakan sebagaimana mestinya, kita tidak boleh menutup mata terhadap hal-hal yang dapat saja muncul sebagai ancaman yang dapat menghambat kinerja dari sistem tersebut. Ancaman-ancaman yang bisa saja muncul dianggap sebagai risiko dan harus ada tindakan yang dilakukan untuk menanggulanginya apabila sistem yang dibangun ingin dapat diaplikasikan dengan baik dan tanpa kendala. Dalam pembentukan sistem pengenalan buah, terdapat berbagai potensi ancaman dapat terjadi pada setiap domain manajemen risiko terkait implementasi Teknologi Informasi. Domain-domain terkait dengan ancaman merupakan bagian alur kerja dari sistem yang meliputi [14]:

- User domain - Ketidak tahuan user dalam penggunaan kamera atau program dari sistem pengenalan buah-buahan;

- Workstation domain - Terdapat virus atau program error sehingga sistem pengenalan buah tidak dapat digunakan;

- LAN domain - Terdapat masalah pada jaringan local sehingga aplikasi tidak dapat digunakan untuk mengenali buah-buahan;

- LAN to WAN domain - Terdapat masalah dalam akses program dan data program (daftar nama buah dan harganya), sehingga saat dijalankan, program tidak bisa mengeluarkan output;

- Remote access domain - Tidak bisa mengeluarkan output karena terdapat masalah pada jaringan local ke pusat (data nama buah dan informasi harga disimpan pada kantor pusat);

- WAN domain - Terdapat masalah pada koneksi dari penyedia layanan internet (ISP);

- System application domain - Terdapat masalah pada aplikasi atau data sehingga aplikasi tidak berjalan lancar.

Ancaman-ancaman tersebut adalah risiko yang mungkin dapat terjadi pada saat sistem pengenalan buah digunakan oleh user. Untuk kemungkinan langkah mitigasinya, bisa dilakukan :

- Membuat tutorial penggunaan sistem yang mudah dimengerti oleh pelanggan;

- Menggunakan perangkat lunak antivirus berbayar;

- Membuat alert system jika jaringan terputus agar dapat langsung ditangani;

- Menyediakan alternatif penyedia jasa layanan internet (ISP) lebih dari 1;

- Membuat time scheduler untuk dapat melakukan update database harga buah secara otomatis.

\section{KESIMPULAN}

Sesuai dengan hasil seperti pada Gambar 15, dapat disimpulkan bahwa sistem yang dibentuk mampu melakukan prediksi hasil informasi nama buah dan harga per satuan kilogram berdasarkan data baru yang diambil dari kamera. Ini adalah prototype yang sebagian besar mewakili rencana awal yang diharapkan, yaitu sistem price checker yang mampu menampilkan informasi mengenai buah dan harganya. Perlu juga diperhatikan dengan adanya sistem ini, maka akan muncul juga berbagai risiko terkait yang perlu dibuat perencanaan mitigasinya, sehingga dapat meminimalkan dampak yang ditimbulkan bagi sistem. 


\section{DAFTAR PUSTAKA}

[1] Olyver Wyman. (2018) The Future Supermarket: How Digital Operations Will Enable a Winning Customer Experience, At Much Lower Cost. [Online]. Tersedia: https://www.oliverwyman.com/ourexpertise/insights/2018/feb/retail-consumer-journal-vol-6/the-futuresupermarket.html

[2] (2019) From smart carts to computer vision, checkouts innovation are multiplying. [Online]. Tersedia: http://www.grocerydive.com/news/from-smart-carts-to-computervision-checkout-innovations-are-multiplying/563425/

[3] (2019) 4 Computer Vision Technologies For Brick and Mortar Stores. [Online]. Tersedia: https://www.clarifai.com/blog/4computer-vision-technologies-for-brick-and-mortar-stores

[4] (2001) Veggie Vision. [Online]. Tersedia: http://www.supermarketnews.com/archive/veggie-vision

[5] S. Prince, Computer Vision: Models Learning and Inference, Cambridge: University Press, 2012.

[6] D. A. Forsyth \& J. Ponce, Computer Vision - A Modern Approach, $2^{\text {nd }}$ ed., Pitman, 2012.

[7] J. E. Solem, Programming Computer Vision with Python, Cambridge: O’Reilly Media, 2012.
[8] R. Szeliski, Computer Vision Algorithms and Applications, London, New York: Springer, 2011.

[9] (2020) The OpenCV website. [Online]. Tersedia: http://www.opencv.org/

[10] (2019) Feature Descriptor. [Online]. Tersedia: http://www.analyticsvidhya.com/blog/2019/09/feature-engineeringimage-introduction-hog-feature-descriptor/

[11] (2016) Histogram of Oriented Gradients. [Online]. Tersedia: http://www.learnopencv.com/histogram-of-oriented-gradients/

[12] (2018) K-Nearest Neighbors. [Online]. Tersedia: http://www.towardsdatascience.com/machine-learning-basics-withthe-k-nearest-neoghbors-algorithm-6a6e71d01761

[13] R. Bolle, J. Connell, N. Haas, R. Mohan \&G. Taubin,"VeggieVision: A Produce Recognition System" IEEE Workshop on Automatic Identification Advanced Technologies., WAIAT-97, , November. 1997, pp. 35-38.

[14] (2018) The Seven Domain of a Typical IT Infrastructure. [Online]. Tersedia: http://www.sis.binus.ac.id/2018/01/15/the-seven-domainof-a-typical-it-infrastructure/ 